\title{
A STUDY OF THE ORIGIN OF HEMLOCK FORESTS IN SOUTHWESTERN NOVA SCOTIA ${ }^{1}$
}

\author{
BY M. L. MILES and E. C. SMITH
}

Miss M. L. Miles was born in Sydney, Nova Scotia in 1940. She was granted a B.Sc. with Honours in Biology by Acadia University in 1960, and has been employed by the Nova Scotia Research Foundation since graduation.

E. C. Smith graduated from Harvard University with a Ph.D. Now he is Professor and Head of the Biology Department, Acadia University and is engaged in research in forest ecology for the Nova Scotia Research Foundation.

\section{ABSTRACT}

$A$ study of neighboring forest stands seventy, one hundred and fifty, and three hundred years old was made in the hemlock area of southwestern Nova Scotia. Soils, drainage and climate were similar. Evidence pointed to fire as the agent in the removal of the original forest in the case of the two younger stands. The number of short-lived trees decreased with the age of the stand, and the abundance and distribution of hemlock indicated its ultimate dominant position. From trends apparent in the younger stands, it appears that having reached an age of three hundred years their composition will be similar to the present composition of the three hundred year old stand. It is concluded that fire may play a major role in the initiation of the development of pure hemlock stands.

\section{INTRODUCTION}

Nova Scotia is placed within the Hemlock - White Pine - Northern Hardwood Forest Region by Nichols (22). This region, although transitional between the boreal forest to the north and the deciduous forest to the south, contains species which are more or less confined to it, and which give the region an ecological distinctness $(22,1)$. These characteristic species are hemlock (Tsuga canadensis (L.) Carr.), red spruce (Picea rubens Sarg.), white pine (Pinus Strobus L.) and yellow birch (Betula lutea Michx. f.).

Rowe (24) included most of the Maritime Provinces within the Acadian Forest Region, which corresponds approximately to the eastern part of the Hemlock - White Pine - Northern Hardwood Region of Nichols. The Nova Scotian portion of the Acadian Forest Region is divided into seven sections. The Tobeatic Area of Queens County where the present study was carried out is located within the Atlantic Uplands Section which covers more than one half of the area of the province. The forest, primarily coniferous, includes a large proportion of hemlock, and red spruce. White and red pine (Pinus resinosa Ait.) and red maple (Acer rubrum L.) are frequently found, while balsam fir (Abies balsamea (L.) Mill.) is present as a minor constituent in mature stands. Pioneer species such as white birch (Betula papyrifera Marsh.), red maple, large-tooth aspen (Populus grandidentata Michx.) are commonly found in disturbed areas. Northern red oak (Quercus rubra L., var.

\footnotetext{
${ }^{1}$ Contribution from the Perry Biological Laboratories, Acadia University, Wolfville, Nova Scotia.
} Cost of publication shared by the Nova Scotia Research Foundation and the C.I.F. 
borealis (Michx. f.) Farw.) and other deciduous species are prominent in some areas, but the general aspect is that of a coniferous forest.

Hemlock occurs in varying amounts throughout the province of Nova Scotia. In Cape Breton Island and in the northeastern portion of the mainland it is relatively rare, occurring mainly mixed with deciduous species on the slopes of ravines and in brook valleys. The species becomes more common toward the southwest, where it occurs in extensive pure stands or mixed with red spruce. The abundance of hemlock in the latter area was reported as early as 1801 by Titus Smith (26). In 1952 Drinkwater (6) estimated that pure stands of hemlock covered approximately 45,000 acres in this region.

Little ecological work has been carried out in this hemlock area. The main studies completed include those of Drinkwater (6) concerned with a virgin hemlock stand, Martin (18) dealing with burned-over land, and Taylor $(28,29)$ describing succession after clearcut of mature hemlock stands.

The position of hemlock in the climax forest throughout its range has received considerable attention, and in particular, the origin and perpetuation of pure stands of this species have been much debated and various theories have been proposed to account for their occurrence. Daubenmire (5) considered edaphic conditions to be the cause of pure stands of hemlock. Graham (10) attributed the occurrence of pure stands to a series of moist summers which favor abundant reproductions of this species. A third view, outlined by Merrill and Hawley (20) proposed that pure stands of hemlock may result from the shade tolerance and longevity of this species. Maissurow (16) regarded fire as a necessary factor in the perpetuation of hemlock stands, whereas other authors regard a combination of factors to be essential.

The characteristic forest of the region in which Nova Scotia occurs is a mixed forest in which even-aged stands of one species are not typical. The suggestions which have been advanced to explain the origin of pure, evenaged stands of hemlock are varied and sometimes confficting. In the present work evidence was sought through study of such stands, together with adjacent younger areas, in an attempt to determine the critical factors in the origin of the Tobeatic hemlock.

\section{Location, Geology, Solls and Climate}

Queens County is situated between $43^{\circ} 45^{\prime}$ and $44^{\circ} 30^{\prime}$ north latitude and $64^{\circ} 30^{\prime}$ west longitude in southwestern Nova Scotia. The Tobeatic Area referred to in this study extends east from the county line to Lake Rossignol and north from East Bay of Jordan Lake to Tobeatic Lake.

Stands of old age hemlock were studied at various locations throughout the area: Coade Lake, Sixth Lake and Seventh Lake. One of these, Coado Lake, is treated here as Stand 1. The 150 year old stand (Stand 2) was located near Eighth Lake, and the 70 year old stand (Stand 3) lay near the Shelburne River west of Lake Rossignol.

The area is characterized by a gently undulating topography with numerous long, low ridges of glacial drift between which are lakes and swamps. There are numerous drumlins and eskers. These present surface conditions represent the effects of glaciation by the Labrador Ice Sheet and by the ice cap which accumulated in western Nova Scotia during the last glaciation (Cameron 
in litt.). The bedrock of the northwestern section is granite. A wide band of slate extends to the east, and to the south there is a wide band of quartzite.

The soil of most of the Tobeatic Area is designated by Cann and Hilchey (3) as Halifax Sandy Loam, with some Danesville Sandy Loam, Gibralter Sandy Loam and peat. All of the sample areas were located on the Halifax Sandy Loam. The parent material of this type is frequently thin with quartzite predominating, and with fragments of slate and granite present. The open, porous nature of the soil permits good drainage (3).

Climatic data were not available from the Tobeatic. The nearest similar inland area from which such data could be obtained was Springfield, Annapolis County, forty miles to the northeast. At this station the mean monthly temperatures as measured over a period of 19 years range from $22^{\circ} \mathrm{F}$. in February to $65^{\circ}$ in July, with an average annual temperature of $44^{\circ} \mathrm{F}$. The frost-free period averages from 110 to 116 days. The average annual precipitation is 85.2 inches, of which 49.5 is rain. One third of this precipitation falls during the growing season.

\section{METHODS}

A quadrat method was used in sampling the vegetation. Square onefortieth acre quadrats were laid out along compass lines in a grid pattern at intervals of $331 / 3$ feet, using a metallic tape.

All trees and shrubs over one foot in height within the quadrats were counted and recorded. Diameter of trees was measured at breast height, this being defined as $4 \frac{1}{2}$ feet from the surface of the ground. The age of a representative sample of the tree species was determined by the use of an increment borer.

Four size classes were adopted for the trees and shrubs. Size Class 1, termed insignificants, included all trees over one foot in height and baving a diameter of less than 0.9 inches; Size Class 2 included small trees ranging in diameter from one inch to 3.5 inches; Size Class 3 included trees with a diameter from 3.6 inches to 9.5 inches; and Size Class 4, large trees with a diameter in excess of 9.6 inches. Because the present study was mainly concerned with the fate of the existing trees, no quantitative data on seedlings or ground cover species were secured. Species-area curves were used to determine the adequacy of the samples.

The quantitative data obtained were summarized in various tables to indicate abundance - the actual number of each present; frequency-an expression of the percentage of sample plots in which the species occurred; and basal area in square feet per acre, determined from diameter at breast height.

The scientific names used are those of Gray's Manual of Botany, Eighth Edition (7).

\section{Stand 1}

\section{RESULTS}

Several stands of old age hemlock in the Rossignol-Tobeatic area were studied by Smith et al. (unpublished) in 1947 (28). Data from one of these near Coade Lake are presented in Tables 1 and 2 in order to give a picture of a typical stand as the basis for comparison with younger stands.

The forest was essentially a pure stand of hemlock with some red spruce, yellow birch and red maple present. No sign of any recent disturbance was 
evident, except for occasional stumps where white pine had been removed many years before. Trees reached a height of approximately eighty feet, and the lower trunks of the trees were free of limbs. While forming a closed canopy, the trees were relatively widely spaced, the density per acre being only 656 trees of all sizes, with 178 above 9.6 inches in diameter. The stand was approximately even-aged with the larger trees being about three hundred years old.

Ground cover consisted almost entirely of a moss carpet in which the principal species were Rhytidiadelphus triquetrus (L., Hedw.) Warnst., Hylocomium splendens (Hedw.) Bry. Sur, and Thuidium delicatulum (L., Hedw.). On rotted stumps and on the trunks of the trees, a liverwort, Bazzania trilobata L. Gray was abundant. In many places where there was a dense layer of needles, growth was absent. Herbaceous species were mainly present where openings had occurred in the canopy and included such species as teaberry (Gaultheria procumbens L.), partridge berry (Mitchella repens L.), starflower (Trientalis borealis Raf.), and wild lily-of-the-valley (Maianthemum canadense Desf.). Shrubs were absent, and there were few seedlings of the tree species. These latter occurred in open areas.

In Table 1 are presented the abundance and frequency per cents of the tree species present in each of the four size classes based on the study of twenty-six quadrats. In Size Class 1, termed insignificant, red spruce had an abundance of 98.2 per cent and was present in all quadrats. Hemlock, beech, and fir were the other species present in this size class but occurred in only one quadrat and had an abundance of less than one per cent.

Species occurring in Size Class 2 included only red spruce with an abundance of 90 per cent, and hemlock with an abundance of 10 per cent. Red spruce in this size class also had a greater frequency than hemlock, values being 77.8 per cent and 15.4 per cent respectively.

Of the trees with diameters between 3.6 and 9.5 inches $48.1 \%$ were hemlock and $42.3 \%$ were red spruce. The remainder of this class was red maple and yellow birch. Hemlock had a frequency of $46.2 \%$ as compared with $27.9 \%$ for red spruce, while yellow birch and red maple were not widely distributed.

TABLE 1

Stand 1: Abundance (A) and Frequency (F) Per Cents for the Four Size Classes of the Principal Tree Species in Old Age Hemlock

\begin{tabular}{|c|c|c|c|c|c|c|c|c|}
\hline \multirow{2}{*}{ Species } & \multirow{2}{*}{\multicolumn{2}{|c|}{$\begin{array}{c}\text { Size Class I } \\
\text { I foot high } \\
\text { to } \\
0.9 \text { inches } \\
\text { D.B.H. }\end{array}$}} & \multicolumn{2}{|c|}{$\begin{array}{c}\text { Size Class } 2 \\
1 \text { to } 3.5 \\
\text { inches D.B.H. }\end{array}$} & \multicolumn{2}{|c|}{$\begin{array}{c}\text { Size Class } 3 \\
3.6 \text { to } 9.5 \\
\text { inches D.B.E. }\end{array}$} & \multicolumn{2}{|c|}{$\begin{array}{l}\text { Size Class } 4 \\
\text { 9.6 inches } \\
\text { D.B.H. }\end{array}$} \\
\hline & & & $\mathrm{A} \%$ & F $\%$ & A\% & $\mathrm{F} \%$ & $\begin{array}{l}\text { an } \\
\mathrm{A} \%\end{array}$ & $\begin{array}{l}\text { aver } \\
\text { Fo\% }\end{array}$ \\
\hline Hemlock & .6 & 3.8 & 10 & 15.4 & 48.1 & 46.2 & 75.3 & 100 \\
\hline Red Spruce & 98.2 & 100 & 90 & 77.8 & 42.3 & 27.9 & 6.2 & 27.9 \\
\hline Red Maple & 0 & 0 & 0 & 0 & 3.8 & 3.8 & 6.2 & 15.4 \\
\hline Fir & .6 & 3.8 & 0 & 0 & 0 & 0 & 0 & 0 \\
\hline Beech & .6 & 3.8 & 0 & 0 & 0 & 0 & 0 & 0 \\
\hline Yellow Birch & 0 & 0 & 0 & 0 & 5.8 & 7.7 & 12.3 & 42.3 \\
\hline
\end{tabular}


In the largest size class hemlock was clearly the most abundant and widely distributed species, with an abundance of $75.3 \%$ and a frequency of $100 \%$. Yellow birch ranked next to hemlock with a much lower abundance of $12.3 \%$ and a frequency of $42.3 \%$. Red spruce and red maple were of minor importance in this size class.

In Table 2 a summary of data for all size classes is presented. Hemlock and red spruce were the only species present in all size classes and had a frequency of $100 \%$. Red spruce had a greater abundance than hemlock due to the large number of insignificants of this species. In terms of basal area, hemlock with a value of 242.9 square feet per acre far outranked red spruce with a value of only 13.8 square feet per acre.

Hemlock was the dominant species in the stand, followed by red spruce and yellow birch. The remaining species, red maple, fir, and beech, were relatively insignificant components of the stand.

\section{Stand 2}

One of the two young growth stands studied was located near Eighth Lake. This remnant of a much more extensive forest which had been clear cut occupied an area at the edge of low lying land near the lake. A total of ten quadrats were studied.

In contrast to Stand 1, a pure stand of hemlock, this forest was of a more mixed nature with three new species present: white pine, large-toothed aspen and white birch. Red spruce, white pine and fir, of minor importance in Stand 1, occupied a more prominent position. Quantities of charcoal in the soil and the presence of characteristic fire species substantiated the view that the stand had originated following fire. The probable date of the fire was considered to be 1798 or shortly before. This determination was based on the age of the oldest trees which included a fire species, large-tooth aspen, and was found to be approximately 150 years at the time when the study was made.

TABLE 2

Stand 1: Abundance and Frequency Per Cents, Size Classes Represented, and Basal Area in Square Feet per Acre of the Principal Tree Species in Old Age Hemlock

\begin{tabular}{|c|c|c|c|c|}
\hline Species & $\begin{array}{c}\text { Abundance } \\
\%\end{array}$ & $\begin{array}{c}\text { Frequency } \\
\%\end{array}$ & $\begin{array}{c}\text { Basal Area } \\
\text { ft. } 2 / \text { acre }\end{array}$ & $\begin{array}{l}\text { Size Classes } \\
\text { Represented }\end{array}$ \\
\hline Hemlock & 26.2 & 100 & 242.95 & $1,2,3,4$ \\
\hline Red Spruce & 67.4 & 100 & 13.8 & $1,2,3,4$ \\
\hline Red Maple & 2.0 & 19.2 & 14.16 & 3,4 \\
\hline Fir & .3 & 3.8 & 0 & 1 \\
\hline Beech & .3 & 3.8 & 0 & 1 \\
\hline Yellow Birch & 3.8 & 46.2 & 50.70 & 3,4 \\
\hline
\end{tabular}

Trees had not yet attained the height of those in Stand 1 and a closed canopy had not developed. Branches were present on the lower part of the trunks, and diameters of trees ranged from less than one inch to twenty inches at breast height. The stand was comparatively dense, with 932 trees per acre in all size classes.

The moss carpet was not so well developed as in the previous stand but 
was composed of the same species. Typical ground cover species were also similar to those of Stand 1, but individual plants were more numerous.

An examination of Table 3 shows that fire with an abundance of $85.4 \%$, and red spruce with $14.6 \%$ were the only constituents of Size Class 1 . Fir was found in six of the ten quadrats while spruce occurred in only two.

Four species were present in Size Class 2, hemlock being the most numerous with an abundance of $69.2 \%$. Red spruce had an abundance of $15.4 \%$, and fir and red maple were present in lesser amounts. Frequency per cents for this size class were low, hemlock being most widely distributed with a frequency of only $30 \%$.

Hemlock was also the most abundant species in Size Class 3 and was found in all quadrats. Red spruce ranked next with an abundance of $36.7 \%$, and had a frequency of $100 \%$. White birch occurred in $50 \%$ of the quadrats but had an abundance of only $7.3 \%$. Several species, white pine, fir, red maple, yellow birch and large-toothed aspen, were insignificant components of this size class.

In the larger size class red spruce was most abundant and had the greatest frequency. Hemlock comprised $16 \%$ of the total present and was somewhat less abundant than white pine which had a value of $17.8 \%$. White birch, largetoothed aspen and red maple were present in small numbers in only a few of the quadrats.

TABLE 3

Stand 2: Abundance (A) and Frequency (F) Per Cents for the Four Size Classes of the Principal Tree Species in the 150 Year Old Stand

\begin{tabular}{|c|c|c|c|c|c|c|c|c|}
\hline \multirow{2}{*}{ Species } & \multicolumn{2}{|c|}{$\begin{array}{c}\text { Size Class } 1 \\
1 \text { foot high } \\
\text { to } \\
\text { 0.9 inches } \\
\text { D. B.H. }\end{array}$} & \multicolumn{2}{|c|}{$\begin{array}{c}\text { Size Class 2 } \\
1 \text { to } 3.5 \\
\text { Inches D.B.H. }\end{array}$} & \multicolumn{2}{|c|}{$\begin{array}{c}\text { Size Class } 3 \\
3.6 \text { to } 9.5 \\
\text { inches D.B.H. }\end{array}$} & \multicolumn{2}{|c|}{$\begin{array}{l}\text { Size Class } 4 \\
9.6 \text { inches } \\
\text { D.B.H. } \\
\text { and over }\end{array}$} \\
\hline & $A \%$ & $\mathrm{~F} \%$ & A\% & F\% & $\mathrm{A} \%$ & F\% & $\mathrm{A} \%$ & F\% \\
\hline Hemlock & 0 & 0 & 69.2 & 30 & 51.2 & 100 & 16.0 & 70 \\
\hline Red Spruce & 14.6 & 20 & 15.4 & 20 & 36.7 & 100 & 51.8 & 100 \\
\hline White Birch & 0 & 0 & 0 & 0 & 7.3 & 50 & 5.4 & 20 \\
\hline Red Maple & 0 & 0 & 7.7 & 10 & 1.6 & 20 & 3.6 & 20 \\
\hline Fir & 85.4 & 60 & 7.7 & 10 & .8 & 10 & 0 & 0 \\
\hline Large-toothed Aspen & 0 & 0 & 0 & 0 & .8 & 10 & 5.4 & 30 \\
\hline White Pine & 0 & 0 & 0 & 0 & .8 & 10 & 17.8 & 60 \\
\hline Yellow Birch & $\mathbf{0}$ & 0 & 0 & 0 & .8 & 10 & 0 & 0 \\
\hline
\end{tabular}

Red spruce was the dominant species with hemlock second in importance. Data given in Table 4 indicate that red spruce was only slightly more abundant than hemlock, but had a basal area of 129.8 square feet per acre whereas the basal area of hemlock was 76.4. Both species were widely distributed in the stand, appearing in all quadrats, but hemlock was present in only the three upper size classes. Fir, white birch and white pine ranked next in terms of abundance, and each had a frequency of $60 \%$. White pine had a basal area of 47 square feet per acre, red spruce 21.6, and the basal area of fir was insignificant. Large-toothed aspen had a basal area of 14.2 square feet 
per acre, occurred in only the two larger size classes, and had a low abundance and frequency. Many of the trees of this species showed signs of decay. Red maple and yellow birch were also minor components of this stand.

Stand 3

A stand of approximately seventy years of age was located near the Shelburne River. This, like Stand 2, apparently originated following fire. Evidence consisted of large amounts of charcoal in the soil, fire scars on the few older trees which survived the fire, and the abundance of fire species such as large-toothed aspen. The oldest tree found in the stand was 82 years, indicating a date of 1866 or just before for the fire.

TABLE 4

Stand 2: Abundance and Frequency Per Cents, Size Classes

Represented, and Basal Area in Square Feet per Acre of the Principal Tree Species in the 150 Year Old Stand

\begin{tabular}{lrcrc}
\hline \multicolumn{1}{c}{ Species } & $\begin{array}{c}\text { Abundance } \\
\%\end{array}$ & $\begin{array}{c}\text { Frequencs } \\
\%\end{array}$ & $\begin{array}{c}\text { Basal Area } \\
\text { ft.2/acre }\end{array}$ & $\begin{array}{c}\text { Size Classes } \\
\text { Represented }\end{array}$ \\
\hline Hemlock - & 34.8 & 100 & 76.4 & $2,3,4$ \\
Red Spruce & 35.1 & 100 & 129.8 & $1,2,3,4$ \\
White Birch & 5.2 & 60 & 21.6 & 3,4 \\
Red Maple & 2.2 & 30 & 7.2 & $2,3,4$ \\
Fir & 15.9 & 60 & 1.4 & $1,2,3$ \\
Large-toothed Aspen - & 1.7 & 30 & 14.2 & 3,4 \\
White Pine & 4.7 & 60 & 47.0 & 3,4 \\
Yellow Birch & .4 & 10 & 1.4 & 3 \\
\hline
\end{tabular}

Several species such as red oak and wire birch, which were absent in the previous stands, occurred in this forest. Trees were relatively short with numerous branches on all parts of the trunk. The stand was very dense, there being roughly 2,300 trees per acre. Diameters of the majority of trees were under ten inches. Ages of the larger trees which originated after the fire ranged from fifty-two to eighty-two years, with the majority being about seventy years old.

The moss carpet under this stand was poorly developed. Herbaceous species were more numerous than in either of the previous stands. In addition to the common species in Stands 1 and 2, others such as blueberry (Vaccinium L.), goldenrod (Solidago L.) and Aster (Tourn.) L. were present.

Abundance and frequency per cents for the four size classes are presented in Table 5. As in Stand 2, ten quadrats were used as a sample of the vegetation. In Size Class 1, hemlock and fir were equally abundant with a value of $5.3 \%$ and both were found in only one quadrat. Red spruce was present in much greater numbers, having an abundance of $89.4 \%$ and occurred in six of the quadrats.

Hemlock and red spruce were the main constituents of Size Class 2, other species being present in only very small amounts. The frequency of hemlock was $100 \%$ and red spruce was distributed throughout seventy per cent of the stand. Abundance per cents were 85.5 for hemlock and 10.1 for red spruce.

Hemlock in Size Class 3 had an abundance of $52.2 \%$, followed by 
white birch with $16.5 \%$, and red spruce and northern red oak, both of which had values of $9.9 \%$. Frequency per cents were 100 for hemlock and white birch, 90 for red oak and 70 for red spruce. Red maple occurred in six quadrats

TABLE 5

Stand 3: Abundance (A) and Frequency (F) Per Cents for the Four Size Classes of the Principal Tree Species in the 70 Year Old Stand

\begin{tabular}{|c|c|c|c|c|c|c|c|c|}
\hline \multirow{2}{*}{ Species } & \multicolumn{2}{|c|}{$\begin{array}{c}\text { Size Class } 1 \\
1 \text { foot high } \\
\text { to } \\
0.9 \text { inches } \\
\text { D.B.H. }\end{array}$} & \multicolumn{2}{|c|}{$\begin{array}{c}\text { Size Class } 2 \\
1 \text { to } 3.5 \\
\text { Inches D.B.H. }\end{array}$} & \multicolumn{2}{|c|}{$\begin{array}{c}\text { Size Class } 3 \\
\text { 3.6 to } 9.5 \\
\text { inches D.B.H. }\end{array}$} & \multicolumn{2}{|c|}{$\begin{array}{l}\text { Size Class } 4 \\
9.6 \text { inches } \\
\text { D.B.H. } \\
\text { and over }\end{array}$} \\
\hline & $A \%$ & F\% & $\mathrm{A} \%$ & F\% & A\% & $\mathbf{F} \%$ & $A \%$ & F\% \\
\hline Hemlock & 5.3 & 10 & 85.5 & 100 & 52.2 & 100 & 0 & 0 \\
\hline Red Spruce & 89.4 & 60 & 10.1 & 70 & 9.9 & 70 & 5.3 & 10 \\
\hline White Birch & 0 & 0 & .3 & 10 & 16.5 & 100 & 0 & 0 \\
\hline Northern Red Oak & 0 & 0 & .3 & 10 & 9.9 & 90 & 36.8 & 50 \\
\hline Red Maple & 0 & 0 & .7 & 20 & 7.4 & 60 & 0 & 0 \\
\hline Fir & 5.3 & 10 & 1.8 & 20 & .8 & 20 & 0 & 0 \\
\hline Large-toothed Aspen & 0 & 0 & $\mathbf{0}$ & 0 & 2.1 & 40 & 42.1 & 50 \\
\hline Beech & 0 & 0 & 1.0 & 20 & 0 & 0 & 0 & 0 \\
\hline White Pine & 0 & 0 & 0 & 0 & .8 & 20 & 15.8 & 20 \\
\hline Yellow Birch & 0 & 0 & .3 & 10 & 0 & 0 & 0 & 0 \\
\hline Wire Birch & 0 & 0 & 0 & 0 & .4 & 10 & 0 & 0 \\
\hline
\end{tabular}

with an abundance of $7.4 \%$. Large-toothed aspen, fir, white pine, and wire birch (Betula populifolia Marsh.) were present in small numbers.

The largest size class contained only four species, most abundant being large-toothed aspen which occurred in $50 \%$ of the quadrats. Northern red oak also had the same frequency and an abundance of $36.8 \%$. White pine was present in two quadrats with an abundance of 15.8 , and red spruce, occurring in one quadrat, had an abundance of only $5.3 \%$.

In Table 6 a summary of data is given. The basal area of hemlock was 104.4 square feet per acre and the corresponding value for red oak was 41.8. Red spruce, white pine, paper birch and large-toothed aspen had basal areas ranging from 20.5 to 38 square feet per acre, while the value for other species present was insignificant. Hemlock and red spruce were the most abundant species, with the other components of the stand being present in small numbers. Six species had frequencies of over $50 \%$, while the remaining five were not well distributed in the stand. Hemlock was the dominant species, with red spruce, red oak, and white birch being important components.

\section{Discussion AND Conclusions}

Stand 1, a pure stand of even-aged hemlock, is typical of much more extensive areas studied by Smith (25) and Drinkwater (6). Even-aged stands of any species are usually regarded as being unusual and develop only after interference of some kind, or as a result of peculiar edaphic conditions. In seeking an explanation for the origin of even-aged old-growth hemlock, the stands of younger growth described above were studied. 
DECEMBER, 1960

TABLE 6

Stand 3: Abundance and Frequency Per Cents, Size Classes Represented, and Basal Area in SQuare Feet per Acre of the Principal Tree Species In the 70 Year Old Stand

\begin{tabular}{|c|c|c|c|c|}
\hline Species & $\begin{array}{c}\text { Abandance } \\
\%\end{array}$ & $\begin{array}{c}\text { Frequency } \\
\%\end{array}$ & $\begin{array}{c}\text { Basal Area } \\
\text { ft. } 2 / \text { acre }\end{array}$ & $\begin{array}{l}\text { Size Classes } \\
\text { Represented }\end{array}$ \\
\hline Hemlock -...- & 66.0 & 100 & 100.4 & $1,2,3$ \\
\hline Red Spruce & 12.5 & 80 & 20.5 & $1,2,3,4$ \\
\hline White Birch & 7.1 & 100 & 30.6 & 2,3 \\
\hline Northern Red Oak & 5.5 & 100 & 41.8 & $2,3,4$ \\
\hline Red Maple & 3.5 & 60 & 13.2 & 2,3 \\
\hline Fir & 1.4 & 40 & 1.6 & $1,2,3$ \\
\hline Large-toothed Aspen & 2.2 & 60 & 38.0 & 3,4 \\
\hline Beech & .5 & 20 & .4 & 2 \\
\hline White Pine & .9 & 20 & 26.0 & 3,4 \\
\hline Yellow Birch & .2 & 10 & .2 & 2 \\
\hline Wire Birch & .2 & 10 & .8 & 3 \\
\hline
\end{tabular}

Various suggestions have been put forth to account for the origin of pure stands of hemlock. Daubenmire (5) found in Indiana that pure stands of this species occurred on dry soil with extreme drainage. Hemlock was able to become established in such a situation whereas more mesic plants required a constant supply of growth water and could not survive. Lutz (15) also noted the ability of hemlock to grow in pure stands on very dry sites. In the Tobeatic area hemlock and hardwood stands occur on the same soil type, so that edaphic conditions do not appear to play a part in the origin of the hemlock stands there and would not account for the even-aged condition observed. Soils in these stands, as previously noted, are well drained but are not excessively dry and there appears to be no other peculiar condition which would influence the type of vegetation.

The general tolerance of hemlock in comparison with other species has been recognized by some authors. Friesner and Potzger (8) found that hemlock could withstand more rigorous environmental conditions than certain hardwood species, and Lutz (15) reported that this species survived under conditions which would be fatal for others. Such severe conditions, however, do not exist in the area studied, and could not account for the abundance of hemlock there.

The tolerance of hemlock to shade and its ability to survive under suppression have also been widely recognized by many authors including Hutchinson (13), Moore et al. (21), Marshall (17) and Graham (11). Merrill and Hawley (20) and Lutz (15) observed that hemlock may become established under other species and owing to its shade tolerance may persist in suppression for long periods of time. Due to the longevity of hemlock, it is possible that it might outlive competing species and form a pure stand. A similar view is presented by Martin (19) who stated that pure stands of hemlock were the climax forest of the ecological region between the deciduous and boreal forests. In a study carried out in Algonquin Park it was found that not only was this 
species able to invade other stands, but hemlock was also the only species able to establish reproduction in its own shade.

While its shade tolerance and long life may permit hemlock to maintain its position of dominance, these factors do not appear to be responsible for the origin of the pure stands in the Tobeatic area. Frothingham (9) described the process of invasion by hemlock, but indicated that the resulting forest would vary widely in age and size, in contrast to the even-aged condition of Stand 1 above. The same author also found that in the dense shade of hemlock and spruce stands, hemlock reproduction was sparse. Stearns (27) and Brown and Curtis (2) reported that hemlock does not reproduce well in its own shade, and Jones (14) stated that young, even-aged stands exclude regeneration by their density. Such would also appear to be the case in Stand 1 of the present study, where hemlock regeneration was insignificant and red spruce was much more abundant (Table 3).

Another theory, proposed by Graham (10), states that the sporadic reproduction of hemlock is responsible for the formation of even-aged stands. This author observed that hemlock reproduction might be absent for long periods due to frequent dry years. Scattered trees may become established in favorable locations, but if there is a series of moist years, mass reproduction may take place resulting in the formation of a pure stand. Oosting and Hess (23) reported that mortality of seedlings was particularly high if a dry year followed the year of establishment. Drinkwater (6) considered a favorable period in the climatic cycle as being of major significance in the origin of the stands which he studied, and Jones (14) reported that irregular seed production can contribute towards an even-aged condition. It is possible that Stand 1 might have originated in this way, but climatic data are insufficient to give conclusive evidence.

Marshall (17) and Hough and Forbes (12) observed that hemlock seeded in best after a disaster which removed the original stand. Jones (14) thought it possible that even-aged stands might originate following fire, or wind throw if on a sufficiently large scale. In northern Wisconsin, Maissurow (16) concluded that hemlock became abundant only after fire, in the absence of which it did not become established on the forest floor.

Other authors suggest that a combination of factors is involved in the origin of even-aged hemlock stands. Hough and Forbes (12) presented the view that such stands originate following large scale catastrophes only if viable seeds and a suitable substrate are present, and if light, soil moisture and other requirements are met. Stearns (27) found that pure stands of hemlock became established following some occurrence which opened up the forest canopy and coincided with favorable seed years and climatic conditions.

Of the three forests included in the present study, two (Stands 2 and 3 ) originated following fire. The data presented above in tables and descriptions give the present state of the three stands.

The abundance, frequency and basal area of the principal species present in all size classes in these stands are compared in Figure 1. Hemlock with a frequency of $100 \%$ in all stands showed an increasing abundance and decreasing basal area from Stand 1 to 3. This was due to the large numbers of 


\section{Hemlock}
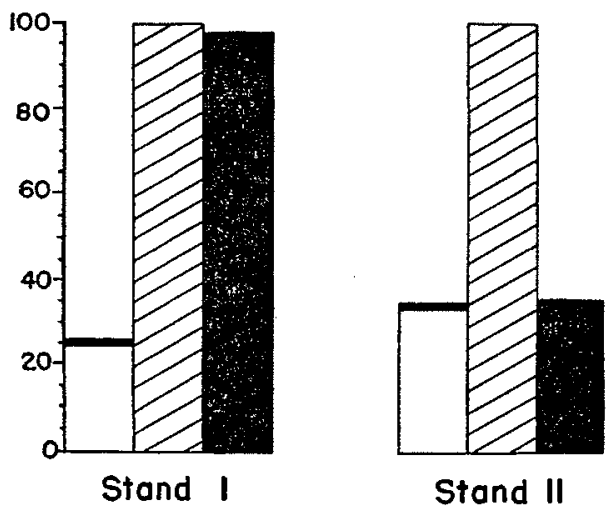

Stand II

Red Spruce

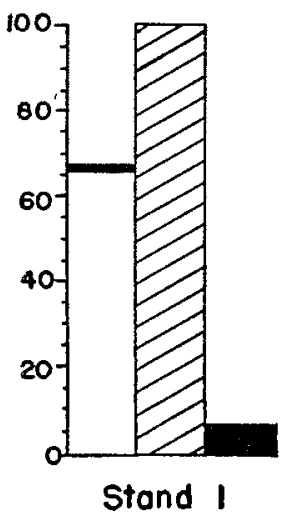

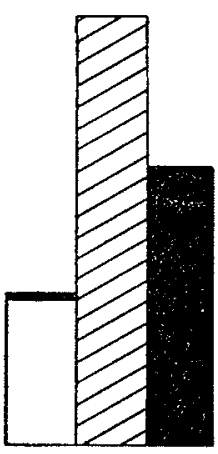

Stand II

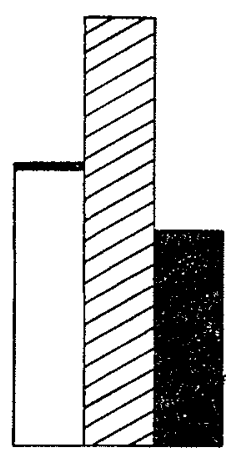

Stand III

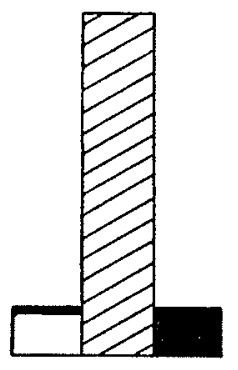

Stand III

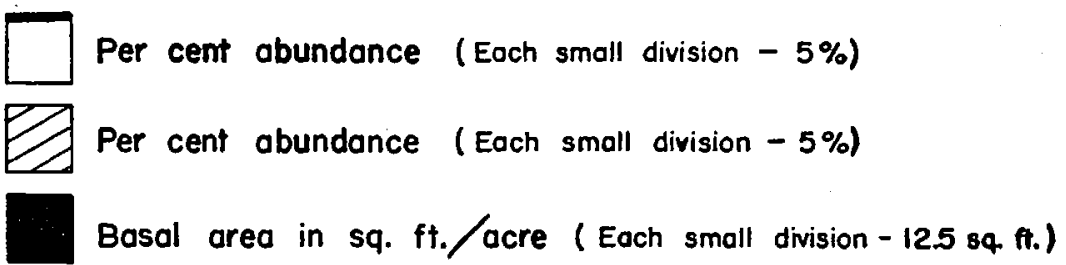

FIGURE 1. Bar diagrams showing abundance and frequency per cents and basal area of the principal tree species in each of the stands. 
386
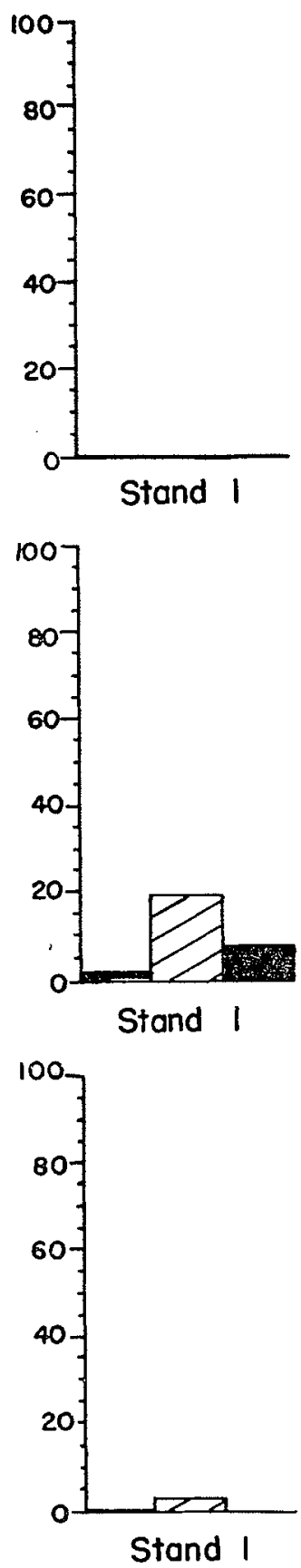

FORESTRY CHRONICLE

White Birch

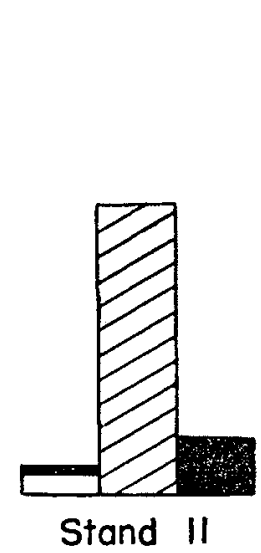

Red Maple

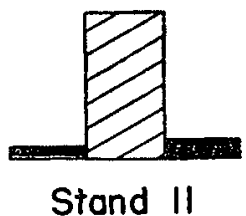

Fir

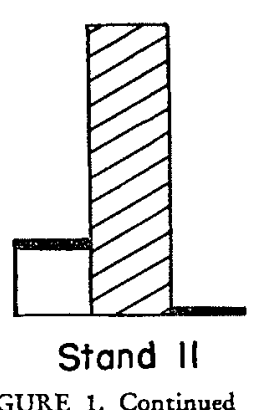

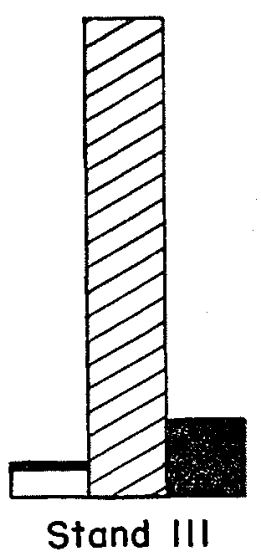

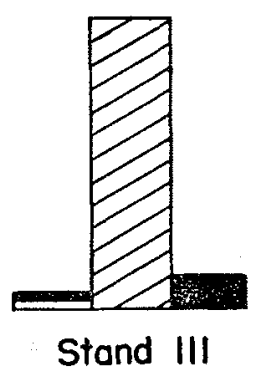

Stand III

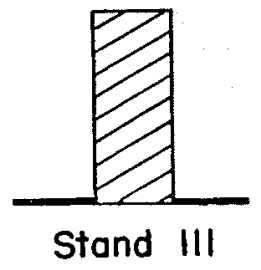


DECEMBER, 1960

1007

Large-toothed Aspen
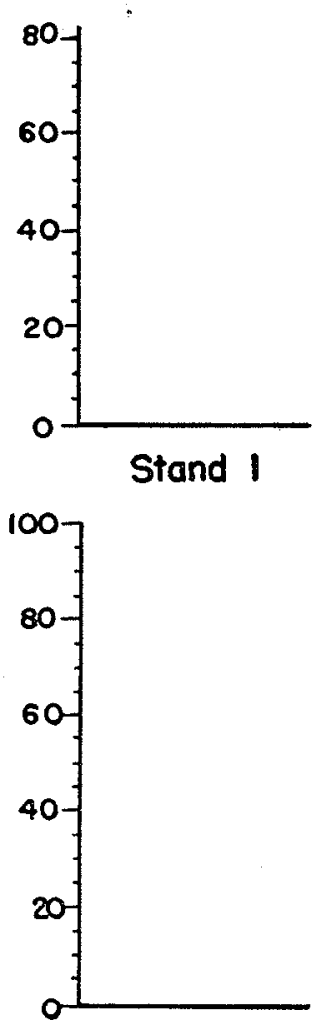

Stand 1
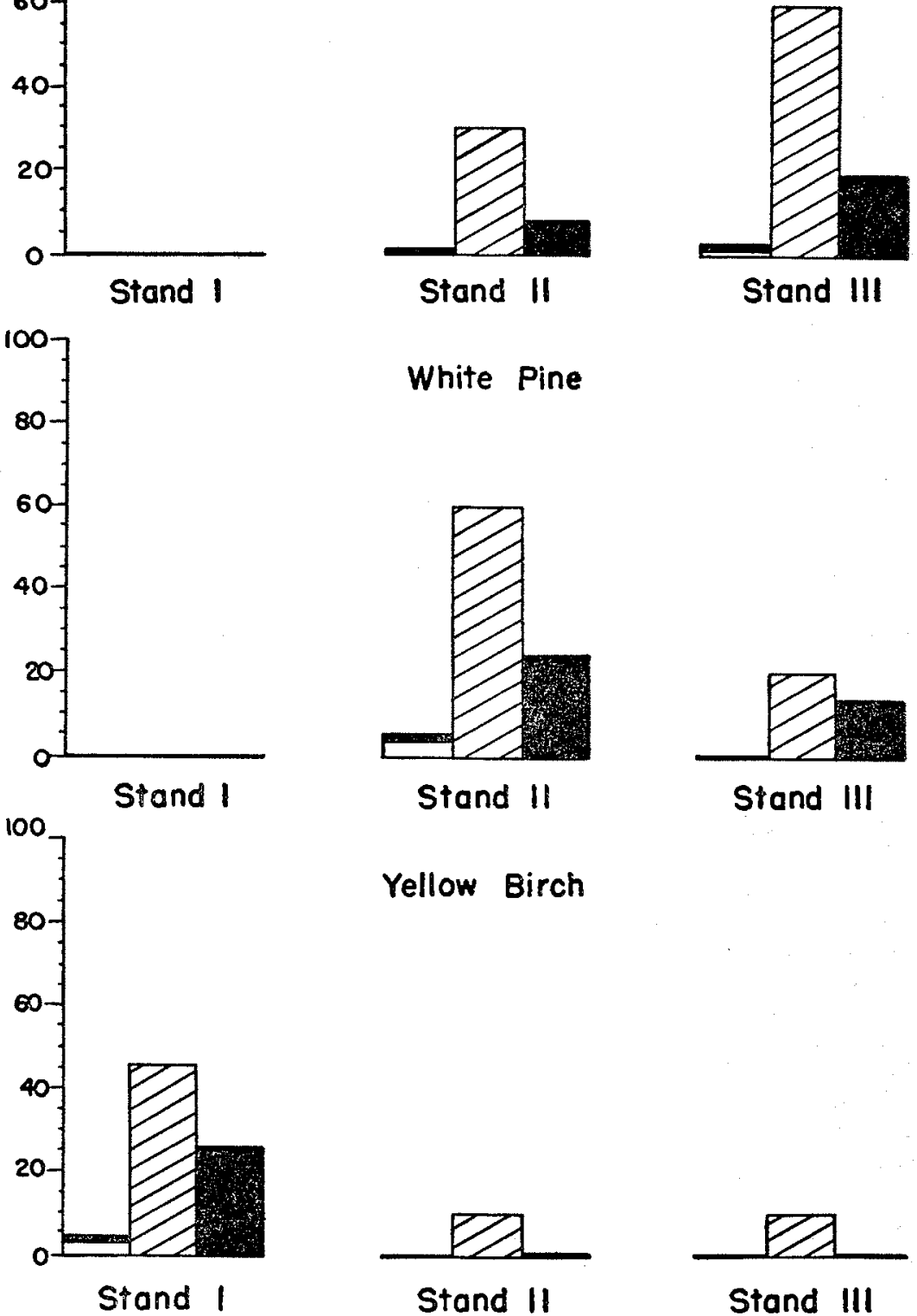

Stand III

White Pine

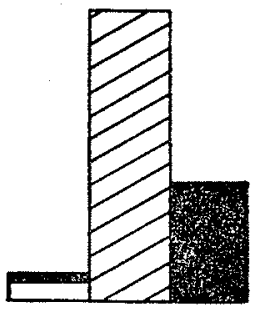

Stand II

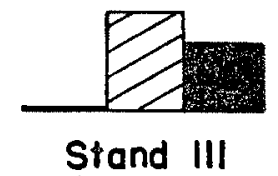

Yellow Birch

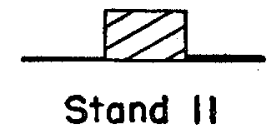

FIGURE 1. Continued

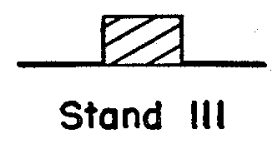


this species in the lower size classes in Stands 2 and 3 (Tables 3 and 5). Clepper (4) reported that hemlock was slow to germinate in areas where forest fires had recently burned. This could account for the scarcity of hemlock in the largest size classes in Stands 2 and 3 (Tables 3 and 5), trees of this species not having been present as long as the largest trees of the species which seeded in first.

Red spruce showed an increase in abundance from Stand 1 to Stand 3, accounted for by the large number of individuals in the lower size classes in theold age forest (Table 1). The basal area for this species was highest in Stand 2, in which it was the leading dominant. It showed a frequency per cent of 100 in Stand 1 (old age hemlock) which was due to the presence of trees of Size Class 1.

Red Maple was of equal importance in all stands, except Stand 3, where it was more widely distributed with a frequency of $60 \%$. In each stand this species was present only in the larger size classes and no trees of Size Class 1 or 2 were found.

As shown in Figure 1, large-toothed aspen and white birth were absent in Stand 1, and showed increasing values in Stands 2 and 3. These species evidently seeded into the younger stands following fire and were unable to reproduce in the forest which developed.

Fir was a comparatively rare species in Stand 1, and in Stand 3, where its frequency was $40 \%$, other values were low. In Stand 2, its abundance and frequency were highest, due to the large percentage of insignificants which were particularly abundant in this stand (Table 3 ).

All values for white pine showed an increase in Stand 2 as compared with Stand 3. In both cases there was no regeneration of this species, and it was present only in the largest size classes (Tables 3 and 5). In Stand 1 white pine was absent but as previously indicated there were signs that trees of this species had been removed.

Yellow birch was of greatest importance in Stand 1 where it occurred in the two upper size classes (Table 2). In all stands this species was not abundant, and its basal area was of significance only in Stand 1.

From trends now evident in the stands of younger growth, it appears that having reached an age of approximately three hundred years their composition will be quite similar to the present composition of Stand 1. In Stand 2, now about 150 years old, large-toothed aspen, already showing signs of decay, and fir will die out within a relatively short period. White birch and red maple attain a maximum age of about two hundred years so that these species will be absent within the next one hundred and fifty years. Red spruce is not so long-lived as hemlock and thus in the resulting stand will be much more insignificant than at present. It is probable then that hemlock will ultimately become the predominent species, occurring with other long-lived species, yellow birch and white pine, and possibly some red spruce. This is essentially the same as the original composition of Stand 1.

A similar development may be expected in Stand 3. Short-lived species such as fir, large-toothed aspen and wire birch will be the first to die out, followed at a later stage by red maple and white birch. This stand, now about 
seventy years of age, in another two hundred and thirty years will consist of hemlock, with comparatively small amounts of white pine, yellow birch, red spruce, and possibly some scattered beech.

Northern red oak, which was absent from Stands 1 and 2 occurred in considerable amounts, and was relatively widespread in Stand 3. Moore et al. (21) suggested that hemlock has the ability to survive beneath the crowns of oak and eventually is successful in crowding out this species. If such is the case it is expected that when the stand has reached three hundred years of age most of the oak will have disappeared. The composition of this stand would then be almost identical with that of Stand 1.

The density per acre of hemlock in the largest size class in Stand 1 was 134 trees out of a total of 178. In Stand 2 the density of this species in the two upper size classes was 288 trees per acre, and in Stand 3 the density was 504 , with a frequency of $100 \%$ in both stands. It would appear that there was an adequate stocking and distribution to form stands similar to Stand 1, a pure stand of hemlock, essentially even-aged with a small admixture of white pine, red spruce, and a few trees of long-lived, deciduous species.

The three stands studied were located within a few miles of one another and thus were subject to essentially the same climatic conditions. All were growing on the same soil type, Halifax Sandy Loam, and existed under similar drainage conditions. They differed in age, density, and somewhat in species composition. It has been shown that the eventual composition of the younger stands, which are known to have originated after fire, will be almost identical with the present composition of Stand 1.

Fire would serve as the agent in the removal of the original forest, and if followed by adequate seeding-in during a time of favorable climatic and seedbed conditions, a pure stand of hemlock could develop in much the same manner as described for Stands 2 and 3. It is concluded that fire could possibly have played a major role in the origin of the pure stands of old-growth hemlock in the Tobeatic area.

\section{ACKNOWLEDGEMENTS}

The authors wish to acknowledge the co-operation of the Mersey Paper Company Limited, who gave permission to use their lands, and the assistance and helpful suggestions of the Chief Forester, Mr. R. S. Johnson. Thanks are extended to all those who assisted in the collection of data during the summers of 1947 and 1948; and the financial support of the Nova Scotia Research Foundation, which made the study possible, is acknowledged.

\section{REFERENCES}

1. BRAUN, E, L. 1950. Deciduous forests of eastern North America. The Blakiston Company.

2. BROWN, $R$. T. and J. T. CURTIS. 1952. The upland conifer-hardwood forests of northern Wisconsin. Ecol. Monog. 22: 217-234.

3. CANN, D. B. and J. D. HILCHEY. 1959. Soil survey of Queens County, Nova Scotia. Report No. 8 Nova Scotia Soil Survey, Truro, N.S.

4. CLEPPER, H. E. 1934. Hemlock-the state tree of Pennsylvania. Bull. 52 Dept. Lands and Forests, $\mathrm{Pa}$.

5. DAUBENMIRE, R. F. 1931. Factors favoring the persistence of a relic association of eastern hemlock in Indiana. Butler Univ. Bot. Studies 2: 29-32. 
6. DRINKWATER, M. H. 1952. A study of development in a virgin hemlock stand. Queens County, Nova Scotia. Canada, Dept, of Res. and Dev. For. Branch Silv. Leaflet No. 72.

7. FERNALD, M. L. 1950. Gray's Manual of Botany 8 th ed. American Book Co., N.Y.

8. FRIESNER, R. C. and J. E. POTZGER. 1932. Studies in forest ecology. The ecological significance of Tsuga canadensis in Indiana. But. Univ. Bot. Studies 2: 145-149.

9. FROTHINGHAM, E. H. 1915. The eastern hemlock. U.S.D.A. Bull. 152: 1-43.

10. GRAHAM, S. A. 1941. The question of hemlock establishment. Jour. For. 39 (6): 567-569.

11. 1943. Causes of hemlock mortality in Northern Michigan. Bull. 10. School of Forestry and Conservation. Univ. of Michigan.

12. HOUGH, A. F. and R. D. FORBES. 1943. Ecology and sylvics of forests in the high plateaus of Pennsylvania. Ecol. Monog. 13: 299-320.

13. HUTCHINSON, A. H. 1918. Limiting factors in relation to specific ranges of tolerance of forest trees. Bot. Gaz. 66: 465-493.

14. JONES, E. W. 1945. The structure and reproduction of the virgin forest of the north temperate zone. The New Phytologist 44(2): 130-148.

15. LUTZ, H. J. 1928. Trends and silvicultural significance of upland forest successions in southern New England. Yale Univ. School For. Bull. 22: 1-68.

16. MAISSUROW, D. K. 1941. The role of fire in the perpetuation of virgin forests of Northern Wisconsin. Jour. Forest. 39: 201-207.

17. MARSHALI, R. 1927. The growth of hemlock before and after suppression. Har. Univ. For. Bull. 11: 1-43.

18. MARTIN, J. L. 1956. An ecological survey of burned-over forest land in southwestern Nova Scotia. Forestry Chronicle 32(3): 313-336.

19. MARTIN, N. D. 1959. An analysis of forest succession in Algonquin Park, Ontario. Ecol. Monog. 29: $187-218$.

20. MERRILL, P. H. and R. C. HAWLEY. 1924. Hemlock: its place in the silviculture of the southern New England forest. Bull. 12. Yale School of Forestry.

21. MOORE, B., H. M. RICHARDS, H. A. GLEASON, and A. B. STOUT. 1924. Hemlock and its environment. I Field Records Bull. N.Y. Bot. Gard, 12: 325-350.

22. NICHOLS, G. E. 1935. The hemlock-white pine-northern hardwood region of eastern North America. Ecol. $16(3)$ : 403-422.

23. OOSTING, H. J. and D. W. HESS. 1956. Microclimate and a relic stand of Tsuga canadensis in the lower Piedmont of North Carolina. Ecol. 37 (1): 28-39.

24. ROWE, J. S. 1959. Forest regions of Canada. Bull. 123. Canada Dept. of Northern Affairs and National Resources, Forestry Branch, Ottawa.

25. SMITH, E. C. 1947-1949. Unpublished notes.

26. SMITH, TITUS. 1801. Public archives of Nova Scotia. 303 Document 4.

27. STEARNS, F. 1951. The composition of the sugar maple-hemlock-yellow birch association in northern Wisconsin. Ecol. 32: 245-265.

28. TAYLOR, J. C. 1955. A study of the succession after cut on old-age hemlock stands in the Tobeatic area. Thesis Acadia University, Wolfville, N.S.

29. - 1959. A preliminary study of forest tree succession after clearcut of mature hernlock stands in southwest Nova Scotia. Forestry Chronicle 35 (1): 50-58. 